\title{
Pengaruh Model Pembelajaran Student Facilitator and Explaining (SFE) Terhadap Kemampuan Berpikir Kritis Siswa pada Materi Aljabar di SMP Negeri 13 Singkawang
}

\author{
Alpandi $^{1}$, Nindy Citroresmi Prihatiningtyas ${ }^{2}$, Nurul Husna ${ }^{3}$ \\ STKIP Singkawang, Singkawang, Indonesia \\ alpandiepan@gmail.com ${ }^{1}$, nindy.citroresmi@gmail.com ${ }^{2}$, nuna_husna@ymail.com ${ }^{3}$
}

\begin{tabular}{ll}
\hline \hline Keywords : & ABSTRACT \\
Student Facilitator and & Penelitian ini bertujuan untuk mengetahui pengaruh model \\
Explaining (SFE), Kemampuan & pembelajaran SFE terhadap kemampuan berpikir kritis siswa, \\
Berpikir Kritis & aktivitas dan motivasi belajar siswa saat pembelajaran dengan \\
& model SFE pada materi aljabar kelas VIII SMP Negeri 13 \\
& Singkawang. Penelitian ini menggunakan desain Quasi \\
& Eksperimental. Populasi dalam penelitian ini adalah semua kelas \\
& VIII SMP Negeri 13 Singkawang yang terdiri dari empat kelas yang \\
& berjumlah 90 siswa. Sampel diambil dengan teknik purposive \\
& sampling. Adapun sampel yang dipilih terdiri dari dua kelas yaitu \\
& kelas VIIID sebagai kelas eksperimen dan kelas VIIIA sebagai kelas \\
& kontrol. Hasil analisis menunjukkan: 1) adanya perbedaan \\
& kemampuan berpikir kritis siswa antara kelas yang menggunakan \\
& model pembelajaran SFE dengan kelas yang menggunakan model \\
& pembelajaran langsung; 2) pengaruh model pembelajaran SFE \\
& terhadap kemampuan berpikir kritis siswa tergolong tinggi; 3) \\
aktivitas belajar siswa secara keseluruhan sangat aktif; 4) motivasi & belajar siswa dikategorikan tinggi. \\
\hline \hline
\end{tabular}

\section{PENDAHULUAN}

Matematika merupakan disiplin ilmu yang mempunyai sifat khas. Kekhasan itu berkenaan dengan ideide atau konsep-konsep abstrak yang tersusun secara hirarkis. Mata pelajaran matematika perlu diberikan kepada semua peserta didik mulai dari sekolah dasar, untuk membekali peserta didik dengan kemampuan berpikir logis, analitis, sistematis, kritis, inovatif dan kreatif, serta kemampuan bekerjasama (Rosmaiyadi, 2017:12). Dalam pembelajaran Matematika, idealnya siswa dibiasakan untuk memperoleh pemahaman melalui pengalaman dan pengetahuannya yang dikembangkan oleh siswa sesuai dengan perkembangan berpikirnya (Prihatiningtyas, 2017:13). Khususnya berpikir kritis, sangat diperlukan bagi kehidupan siswa, agar mereka mampu menyaring informasi, memilih layak atau tidaknya suatu kebutuhan, yang terkadang masih memiliki kesalahan.

Menurut Ennis (dalam Fisher, 2009:4) berpikir kritis adalah pemikiran yang masuk akal dan reflektif yang berfokus untuk memutuskan apa yang mesti dipercaya atau dilakukan. Reflektif artinya mempertimbangkan atau memikirkan kembali segala sesuatu yang dihadapinya sebelum mengambil keputusan. Beralasan artinya memiliki keyakinan dan pandangan yang didukung oleh bukti yang tepat, aktual, cukup, dan relevan. Seseorang yang berpikir kritis memiliki karakter khusus yang dapat diidentifikasi dengan melihat bagaimana seseorang menyikapi suatu masalah. Informasi berargumen dan memanfaatkan intelektualnya dan pengetahuannya. Pentingnya kemampuan berpikir kritis 
dinyatakan dalam Permendiknas Nomor 23 Tahun 2006 yang mengesahkan Standar Kompetensi Lulusan (SKL) Mata pelajaran Matematika di SMP/MTS yang mencakup tujuan pembelajaran matematika salah satunya ialah siswa harus memiliki kemampuan berpikir logis, analitis, sistematis, kritis dan kreatif, serta mempunyai kemampuan untuk bekerjasama. Dari lima kemampuan berpikir tersebut kemampuan berpikir kritis dan kreatif termasuk dalam kemampuan tingkat tinggi. Kemampuan berpikir kritis melatih cara berpikir dan bernalar siswa dalam menarik kesimpulan serta menggunakan ide-ide matematika dalam kehidupan sehari-hari.

Sejalan dengan tujuan Permendiknas Nomor 23 Tahun 2006 tersebut, Haryani (2012:165-166) menyatakan berpikir kritis sangat penting karena dalam kehidupan sehari-hari cara seseorang mengarahkan hidupnya bergantung pada pernyataan yang dipercayainya, pernyataan yang diterimanya. Selanjutnya secara lebih berhati-hati mengevaluasi suatu pernyataan kemudian membagi pendapat-pendapat yang ada apakah relevan atau tidak dengan pernyataan yang dievaluasi. Selain itu Johnson (2011:183) menyatakan bahwa berpikir kritis memungkinkan siswa untuk mempelajari masalah secara sistematis, menghadapi berjuta tantangan dengan cara yang terorganisasi, merumuskan pertanyaan inovatif, dan merancang solusi orisinil. Munafiah (2015:3) mengungkapkan ada tiga alasan mengapa guru harus melatih kemampuan siswa untuk bisa menggunakan proses berpikir kritis: 1) untuk mengerti informasi; 2) untuk proses berpikir yang berkualitas; 3) untuk hasil akhir yang berkualitas. Ketiga alasan ini melibatkan proses berpikir yang bersifat kreatif dan kritis. Berpikir kritis dapat membantu siswa memahami bagaimana memandang diri sendiri, bagaimana memandang dunia dan bagaimana siswa dalam berhubungan dengan orang lain.

Pada dasarnya kemampuan berpikir kritis erat kaitannya dengan proses berpikir kritis dan indikatorindikatornya. Fisher (2009:8) menyatakan beberapa indikator kemampuan berpikir kritis yang sangat penting yaitu mengidentifikasi dan mengevaluasi asumsi, mengklarifikasi dan menginterpretasi pernyataan-pernyataan dan gagasan, mengevaluasi argumen-argumen yang beragam jenis, menghasilkan argumen-argumen, dan menganalisis dan menghasilkan penjelasan-penjelasan serta membuat keputusan. Sedangkan menurut Santoso (2009:35) terdapat lima indikator sistematis dalam berpikir kritis, yaitu keterampilan menganalisis, keterampilan mensintesis, keterampilan mengenal dan memecahkan masalah, keterampilan menyimpulkan, dan keterampilan mengevaluasi atau menilai.

Dari beberapa pendapat sebelumnya, dapat disimpulkan bahwa kemampuan berpikir kritis merupakan kemampuan siswa dalam pemecahan masalah, pengambilan keputusan (kesimpulan), merumuskan pertanyaan inovatif dan memahami informasi yang didapatkan secara rasional, sistematis, terorganisir dari berbagai aspek dan sudut pandang. Kemampuan berpikir kritis adalah modal intelektual yang penting dimiliki oleh siswa jika berhadapan dengan permasalahan- permasalahan dalam kehidupannya sehari-hari. Kemampuan ideal demikian diharapkan dapat dicapai melalui proses pembelajaran yang dirancang dengan baik.

Namun kenyataannya saat ini siswa belum mampu memanfaatkan kemampuan berpikir kritisnya dalam menyelesaikan soal matematika. Menurut Buyung, B., Sumarli, S., \& Rosmaiyadi, R. (2020) lemahnya kemampuan siswa dalam memahami persoalan dan prosedural dalam soal matematika yang berkaitan dengan kehidupan sehari-hari untuk menyelesaikan soal.. Kurang mampunya siswa dalam berpikir kritis dinyatakan dengan hasil penelitian Nur'aini (2015) yang menunjukkan bahwa kemampuan berpikir kritis matematis siswa SMP Negeri 7 Singkawang masih tergolong rendah. Berdasarkan analisis data, diperoleh kesimpulan bahwa: (1) kemampuan memahami, menjelaskan, dan memberi makna data atau informasi sebesar 89,39\%; (2) kemampuan untuk mengidentifikasi hubungan dari informasi yang digunakan untuk mengekspresikan pemikiran atau pendapat sebesar 70,71\%; (3) kemampuan untuk menjelaskan dan menyatakan hasil pemikiran berdasarkan bukti, metodologi, dan konteks sebesar 39,73\%; (4) kemampuan mengidentifikasi dan memperoleh unsur-unsur yang diperlukan untuk membuat suatu kesimpulan sebesar $28,28 \%$. Rendahnya kemampuan berfikir kritis matematis siswa juga terlihat dari 
hasil prariset yang dilakukan peneliti di SMP Negeri 13 Singkawang.

Selain melakukan prariset, peneliti juga melakukan observasi selama praktek pengalaman lapangan di SMP Negeri 13 Singkawang untuk melihat aktivitas siswa selama proses pembelajaran matematika. Hasil observasi yang diperoleh peneliti adalah aktivitas siswa masih tergolong rendah. Hal ini terlihat dari kurangnya keterlibatan siswa baik secara fisik maupun mental, sehingga siswa tidak aktif baik itu dalam berfikir, berkomunikasi mengemukakan pendapat, bertanya dan bekerjasama saling sharing ide-ide sehingga materi kurang melekat pada ingatan siswa. Akibatnya, aktivitas siswa lebih banyak diam, menyimak penjelasan guru, mencatat serta mengerjakan tugas yang diberikan guru. Aktivitas adalah keseluruhan kegiatan siswa yang dilakukan selama proses pembelajaran yang sudah berlangsung (Kusumaningrum, 2013:11). Sardiman (2014:96) menjelaskan bahwa aktivitas merupakan prinsip atau asas yang sangat penting di dalam interaksi belajar-mengajar. Hal tersebut dikarenakan pada dasarnya belajar adalah berbuat, tanpa adanya aktivitas, kegiatan belajar tidak akan tercipta. Hal ini menunjukkan bahwa setiap orang yang bekerja harus aktif sendiri, tanpa adanya aktivitas maka proses belajar tidak mungkin terjadi.

Aktivitas siswa didalam kelas yang terlihat pasif mengambarkan bahwa motivasi siswa terhadap pembelajaran matematika kurang, siswa terkadang tampak bermain-main dengan temannya sehingga tidak mendengarkan penjelasan guru. Hal tersebut menjadi salah satu faktor rendahnya kemampuan berpikir kritis siswa. Menurut Sumarna (2013:19) motivasi adalah kondisi psikologis yang mendorong seseorang untuk melakukan sesuatu atau kekuatan yang terdapat dalam diri organisme yang mendorong untuk berbuat. Adapun menurut Lestari dan Yudhanegara (2015:93) motivasi belajar adalah suatu daya, dorongan atau kekuatan baik yang datang dari diri sendiri maupun dari luar yang mendorong siswa untuk belajar. Motivasi berfungsi mendorong manusia untuk bebuat, sebagai penggerak atau motor yang melepaskan energi. Motivasi dalam hal ini merupakan motor penggerak dari setiap kegiatan yang akan dikerjakan

Dari beberapa pendapat ahli di atas dapat disimpulkan bahwa aktivitas adalah keseluruhan kegiatan siswa baik fisik ataupun psikis yang dilakukan selama proses pembelajaran berlangsung. Sedangkan motivasi adalah kecenderungan dalam diri siswa yang berupa perasaan senang, perhatian, kemauan, konsentrasi dan kesadaran siswa untuk merasa tertarik mempelajari mata pelajaran matematika. Aktivitas dan motivasi merupakan hal penting yang diperlukan setiap siswa untuk mencapai pembelajaran yang efektif di dalam kelas.

Selama peneliti Praktek Pengalaman Lapangan (PPL) di SMP Negeri 13 Singkawang, terlihat penyebab permasalahan yang paling dominan yaitu guru yang masih menjadi sentral utama (teacher centered), ketidaksesuaian penerapan proses pembelajaran di kelas dengan proses pembelajaran yang tertera di dalam RPP dan kurang tepatnya dalam memilih strategi yang di terapkan dalam kegiatan pembelajaran. Hal ini dapat dilihat dari metode-metode pembelajaran yang diterapkan oleh guru seperti metode ceramah, tanya jawab, dan penugasan sehingga selama proses pembelajaran hanya terpusat pada guru. Ompusunggu (2014:2) menyatakan bahwa banyak faktor yang menjadi penyebab rendahnya kemampuan siswa, salah satu penyebabnya adalah strategi pembelajaran yang dilaksanakan oleh guru yang masih tradisional, yaitu siswa masih diperlakukan sebagai objek belajar dan guru lebih dominan berperan dalam pembelajaran.

Oleh karena itu, diperlukan suatu upaya untuk meningkatkan kemampuan berpikir kritis siswa, misalnya dengan memilih dan menggunakan berbagai pendekatan, strategi, metode dan model pembelajaran yang relevan dengan kondisi siswa. Model pembelajaran yang digunakan dalam pembelajaran matematika seharusnya dapat menimbulkan minat siswa untuk belajar, menyenangkan dan bermakna agar siswa yang mengikuti proses belajar mengajar tidak bosan dan dapat mengikuti pelajaran dengan baik (Rolia dkk, 2017:75). Satu diantara model pembelajaran matematika yang dapat digunakan untuk mengatasi masalah rendahnya kemampuan berpikir kritis matematis siswa adalah dengan menggunakan model Student Facilitator and Explaining (SFE). 
Model Student Facilitator and Explaining (SFE) merupakan rangkaian penyajian materi ajar yang diawali dengan penjelasan secara terbuka, memberi kesempatan siswa untuk menjelaskan kembali kepada siswa lain, dan diakhiri dengan penyampaian semua materi kepada siswa (Huda, 2014:228). Sedangkan menurut Langgeng (2012:22) model Student Facilitator and Explaining (SFE) mempunyai arti model yang menjadikan siswa dapat membuat peta konsep maupun bagan untuk meningkatkan kreatifitas siswa dan prestasi belajar siswa. Artinya pembelajaran matematika bukan hanya penguasaan kumpulan pengetahuan yang berupa fakta- fakta, konsep-konsep, atau prinsip-prinsip saja tetapi juga merupakan suatu proses penemuan akan dapat tercapai dengan baik. Hal ini tentu akan sangat menyenangkan bagi siswa. Apabila siswa sudah merasa senang dalam pelajaran, maka prestasi belajar mereka tentu akan meningkat.

Secara garis besar, model SFE dibagi menjadi tujuh tahapan yaitu informasi kompetensi, sajian materi, siswa mengembangkan materi, siswa menjelaskan pada siswa lain, kesimpulan, evaluasi, dan refleksi (Istarani, 2015:159). Dari beberapa tahapan dalam pembelajaran Student Facilitator and Explaining (SFE), pada tahap guru memberikan kesempatan kepada siswa untuk menjelaskan kepada siswa lainya, memungkinkan siswa dapat mengembangkan kemampuan berpikir kritis karena pada tahap ini siswa diharuskan mampu mengindentifikasi informasi yang diterima dengan ide-ide yang dimiliki oleh siswa itu sendiri. Sehingga siswa mampu menjelaskan kepada siswa lainnya tanpa harus terpaku pada guru.

Dengan proses pembelajaran seperti ini siswa dapat meningkatkan keaktifan, minat, motivasi dan kreativitas siswa dalam berfikir sehingga proses belajar akan lebih menarik dan menyenangkan. Siswa tidak hanya menjadi objek pembelajaran, tetapi juga sebagai subjek yang dapat mengalami, menemukan, mengkonstruksikan, dan memahami konsep dengan cara melakukan atau memanipulasi benda, menggunakan indera mereka, menjelajahi lingkungan, baik lingkungan berupa benda, tempat serta peristiwa-peristiwa disekitar mereka (pengalaman nyata).

Penelitian ini bertujuan untuk mengetahui pengaruh model pembelajaran Student Facilitator and Explaining (SFE) terhadap kemampuan berpikir kritis siswa, mengetahui aktivitas dan motivasi belajar siswa saat pembelajaran dengan model pembelajaran Student Facilitator and Explaining (SFE) pada materi aljabar kelas VIII SMP Negeri 13 Singkawang.

\section{METODE}

Jenis penelitian ini adalah jenis penelitian kuantitatif dengan metode eksperimen. Desain penelitian yang digunakan dalam penelitian ini adalah quasi-eksperimental design dengan rancangan nonequivalent posttest-only control group design. Terdapat dua kelas dalam penelitian ini yaitu kelas pertama disebut sebagai kelas eksperimen dan kelas kedua disebut sebagai kelas kontrol. Menurut Lestari dkk (2015:136) rancangan nonequivalent posttest-only control group design memiliki dua kelompok, yaitu kelompok eksperimen dan kelompok kontrol, penelitian dengan rancangan nonequivalent posttest-only control group design ini menggunakan tes akhir atau posttest untuk melihat perbedaan antara kelompok yang diberikan perlakuan dengan kelompok kontrol. Adapun sekolah yang menjadi tempat penelitian adalah di SMP Negeri 13 Singkawang kelas VIII yang beralamat di Jalan Wonosari Kelurahan Sekip Baru Kecamatan Singkawang Tengah. Populasi dalam penelitian ini adalah seluruh kelas VIII SMP Negeri 13 Singkawang yang terdiri dari empat kelas yaitu VIII A, VIII B, VIII C, VIII D yang berjumlah 90 siswa. Teknik pengambilan sampel pada penelitian ini dengan menggunakan teknik purposive sampling. Adapun yang menjadi kelas eksperimen adalah kelas VIIID dan kelas kontrol adalah kelas VIIIA. Teknik analisis data yang digunakan dalam penelitian ini adalah analisis kuantitatif dengan statistika. Dalam penelitian ini akan diperoleh data kuantitatif sehingga untuk menganalisis data didapatkan dari pemberian tes hasil belajar berupa posttest, pengamatan menggunakan lembar aktivitas dan motivasi menggunakan lembar angket akan dilakukan teknik statistik. 


\section{HASIL DAN PEMBAHASAN}

Setelah melaksanakan penelitian, peneliti mendapatkan nilai posttest, lembar observasi aktivitas belajar siswa, dan angket motivasi belajar siswa. Kemudian data diolah untuk menjawab rumusan masalah pada penelitian ini yaitu perbedaan kemampuan berpikir krtitis siswa kelas eksperimen dan kelas kontrol, seberapa besar pengaruh model pembelajaran SFE, aktivitas dan motivasi belajar siswa terhadap pembelajaran dengan model pembelajaran SFE.

\section{Kemampuan Berpikir Kritis}

Hasil pengumpulan data selama penelitian diperoleh data hasil posttest (berupa skor) dari kelas yang diajarkan dengan model pembelajaran Student Facilitator and Explaining (SFE) untuk kelas eksperimen dan pembelajaran langsung untuk kelas kontrol terhadap kemampuan berpikir kritis siswa pada materi aljabar. Penilaian kemampuan berpikir kritis siswa dinilai dari skor rata-rata kemampuan berpikir kritis siswa. Adapun soal posttest yang diberikan berbentuk tes kemampuan berpikir kritis sebanyak tiga soal dengan empat indikator yaitu: (a) Kemampuan mengenal dan memecahkan masalah; (b) Kemampuan mensintesis; (c) Kemampuan menganalisis; (d) Kemampuan mengevaluasi. Rata-rata untuk setiap indikator kemampuan berpikir kritis siswa dari kelas eksperimen dan kelas kontrol disajikan dalam diagram berikut.

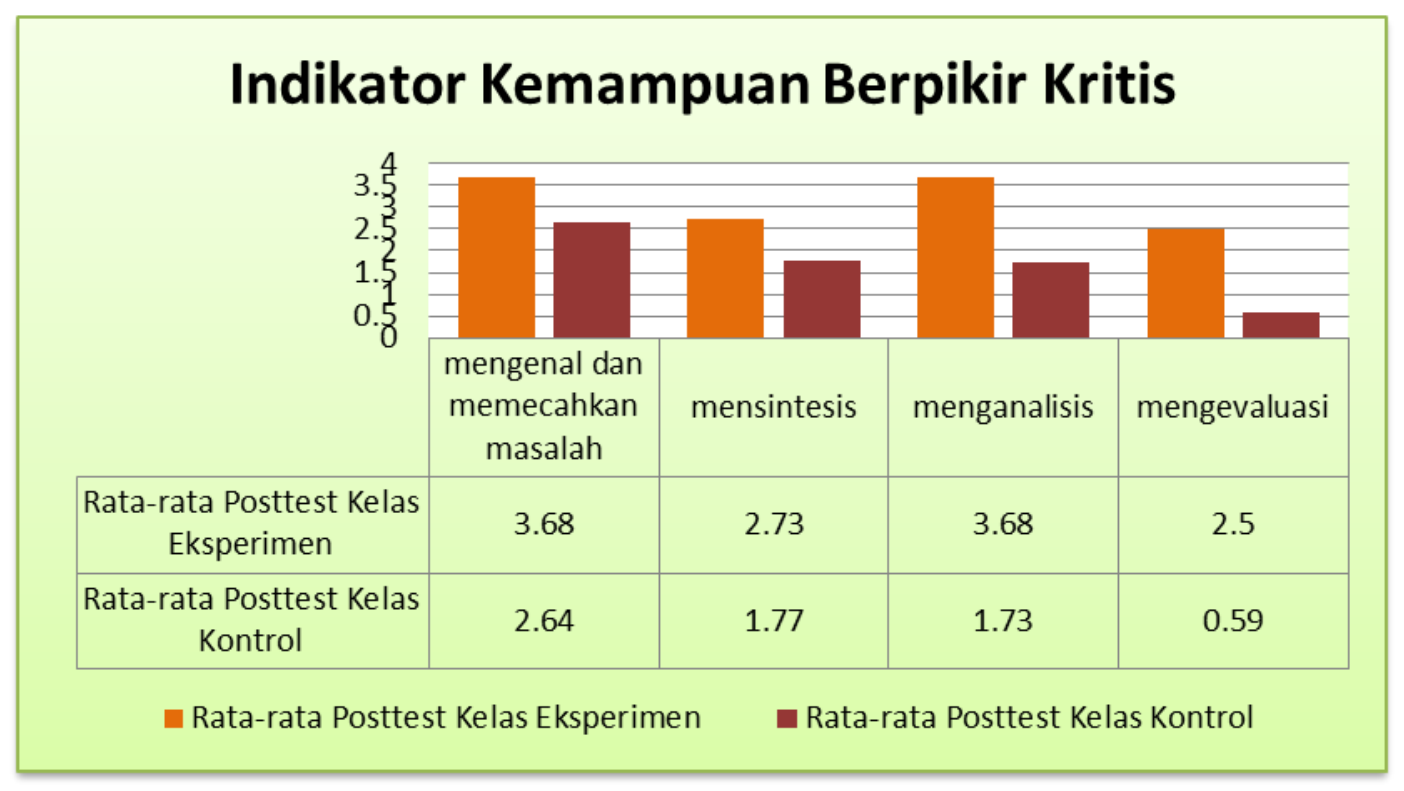

\section{Gambar 1. Diagram Batang Rata-rata Kemampuan Berpikir Kritis Siswa Kelas Eksperimen dan Kelas Kontrol}

Dari Gambar 1 diketahui bahwa rata-rata indikator kemampuan berpikir kritis siswa kelas eksperimen lebih tinggi daripada rata-rata indikator kemampuan berpikir kritis siswa kelas kontrol. Selanjutnya secara keseluruhan rata-rata hasil posttest kemampuan berpikir kritis siswa kelas eksperimen dan kelas kontrol dapat dilihat pada gambar diagram batang 2 sebagai berikut. 


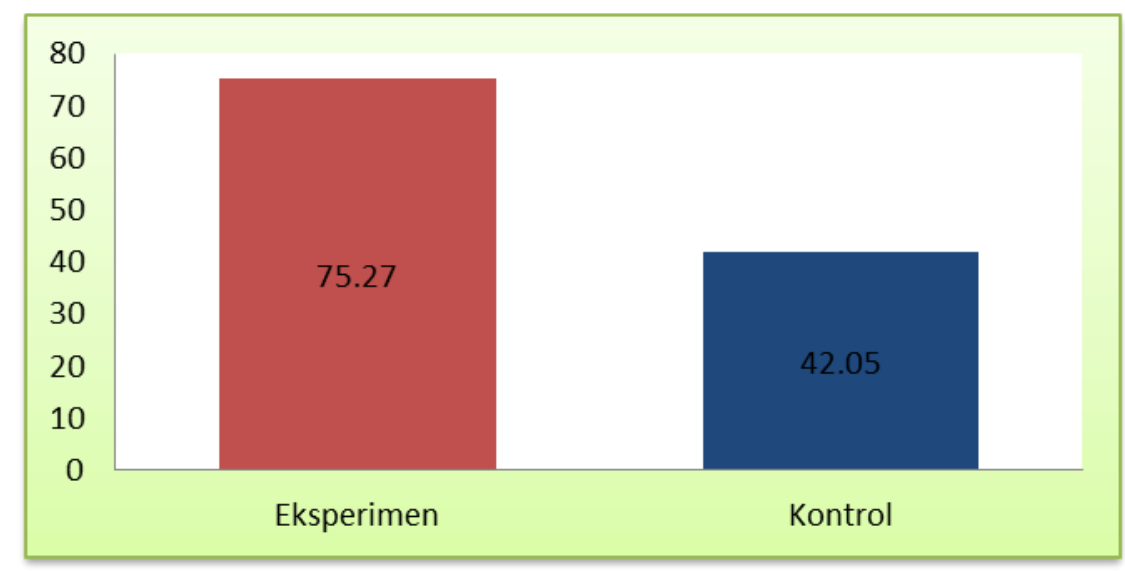

Gambar 2. Diagram Batang Rata-rata Nilai Posttest Kelas Ekperimen dan Kelas Kontrol

Dari gambar 1 dan 2 menunjukan bahwa secara deskriptif rata-rata posttest antara kelas kontrol dan kelas eksperimen berbeda, namun secara inferensial nilai tersebut belum tentu memiliki perbedaan yang signifikan. Untuk melihat perbedaan antara kelas yang menggunakan model pembelajaran Student Facilitator and Explaining (SFE) dengan kelas yang menggunakan model pembelajaran langsung (kelas kontrol) maka menggunakan uji-t dua sampel independen. Namun sebelumnya dilakukan uji normalitas dan uji homogenitas. Berdasarkan hasil perhitungan, untuk data posttest kelas eksperimen dan kontrol disajikan ada Tabel 1 sebagai berikut.

Tabel 1. Rekapitulasi Perhitungan Uji Normalitas

\begin{tabular}{lrlllll}
\hline Kelompok & \multicolumn{2}{l}{$\begin{array}{l}\text { Taraf } \\
\text { Signifikan }\end{array}$} & $\begin{array}{l}x^{2} \\
\text { Hitung }\end{array}$ & $x^{2}$ Tabel & Kesimpulan \\
\hline Eksperimen & 2 & $5 \%$ & 8,697 & 9,488 & $\begin{array}{l}\text { Data } \\
\text { Normal }\end{array}$ & Berdistribusi \\
\hline Kontrol & 2 & $5 \%$ & 6,316 & 9,488 & $\begin{array}{l}\text { Data } \\
\text { Normal }\end{array}$ & Berdistribusi \\
\hline
\end{tabular}

Setelah data skor posttest kelas eksperimen dan kelas kontrol dihitung dan didapatkan hasil data berdistribusi normal, selanjutnya akan dilakukan uji homogenitas data. Untuk pengujian homogenitas dalam penelitian ini menggunakan rumus uji- $F$. Adapun hasil perhitungan uji homogenitas data posttest kelas eksperimen dan kontrol disajikan ada Tabel 2 sebagai berikut.

Tabel 2. Rekapitulasi Perhitungan Uji Homogenitas

\begin{tabular}{cccc}
\hline Kelompok & Db & Varians & $\begin{array}{c}\text { Taraf } \\
\text { Signifikan }\end{array}$ \\
\hline Eksperimen & 22 & 218,02 & $5 \%$ \\
\hline Kontrol & 22 & 350,86 & $5 \%$ \\
\hline $\boldsymbol{F}_{\text {hitung }}$ & $\mathbf{1 , 6 1}$ \\
\hline $\boldsymbol{F}_{\text {tabel }}$ & $\mathbf{2 , 0 5}$ \\
\hline Keterangan & Homogen \\
\hline
\end{tabular}

Dari Tabel 1 dan 2 diketahui bahwa data posttest kelas eksperimen dan kelas kontol berdistribusi normal dan homogen. Maka untuk mengetahui perbedaan penggunaan model pembelajaran $S F E$ dan model pembelajaran langsung peneliti menggunakan uji Independent Sample T-Test. Adapun rekapitulasi hasil perhitungan perbedaan penggunaan model pembelajaran $S F E$ dan model 
pembelajaran langsung terhadap kemampuan berpikir kritis matematis siswa dapat dilihat pada Tabel 3 berikut.

Tabel 3. Rekapitulasi Perhitungan Uji T

\begin{tabular}{lcclcc}
\hline Kelompok & $\mathrm{dk}$ & $S_{\text {gabungan }}$ & $\begin{array}{l}\text { Taraf } \\
\text { Signifikan }\end{array}$ & $T_{\text {hitung }}$ & $T_{\text {tabel }}$ \\
\hline $\begin{array}{l}\text { Eksperimen } \\
\text { dan Kontrol }\end{array}$ & 42 & 16,11 & $5 \%$ & 6,90 & 2,018 \\
\hline
\end{tabular}

Dari Tabel 3 di atas terlihat bahwa nilai $\mathrm{T}_{\text {hitung }}=6,90$. Berdasarkan kriteria pengujian maka penggunaan model pembelajaran $S F E$ dan model pembelajaran langsung terhadap kemampuan berpikir kritis matematis siswa dikatakan memiliki perbedaan apabila $T_{\text {hitung }}>T_{\text {tabel }}$ atau $\mathrm{H}_{\mathrm{o}}$ ditolak $\mathrm{H}_{\mathrm{a}}$ diterima, sebaliknya dikatakan tidak ada perbedaan penggunaan model pembelajaran $S F E$ dan model pembelajaran langsung terhadap kemampuan berpikir kritis matematis siswa apabila $T_{\text {hitung }} \geq T_{\text {tabel }}$ atau $\mathrm{H}_{\mathrm{a}}$ ditolak $\mathrm{H}_{\mathrm{o}}$ diterima. Diketahui $T_{\text {hitung }}>T_{\text {tabel }}$ atau 6,90 $>2,018$, maka $\mathrm{H}_{\mathrm{o}}$ ditolak $\mathrm{H}_{\mathrm{a}}$ diterima. Dapat disimpulkan bahwa terdapat perbedaan penggunaan model pembelajaran SFE dan model pembelajaran langsung terhadap kemampuan berpikir kritis matematis siswa pada materi aljabar kelas VIII SMP Negeri 13 Singkawang.

Perbedaan kemampuan berpikir kritis matematis antara kelas eksperimen dan kelas kontrol disebabkan karena proses pembelajaran dengan model SFE memiliki tahap-tahap yang membuat siswa lebih aktif dan lebih dapat memahami materi. Guru tidak sekadar memberikan pengetahuan kepada siswa, melainkan memfasilitasi siswa untuk membangun pengetahuannya sendiri sehingga siswa memiliki pemahaman yang lebih mantap terhadap materi aljabar.

Selanjutnya untuk melihat seberapa besar pengaruh model pembelajaran SFE terhadap kemampuan berpikir kritis matematis siswa, maka digunakan rumus Effect Size. Adapun hasil perhitungan Effect Size dapat dilihat pada Tabel 4 sebagai berikut.

Tabel 4. Rekapitulasi Hasil Uji Effect Size

\begin{tabular}{ccc}
\hline Kelas & Nilai Rata-rata & $\begin{array}{c}\text { Standar Deviasi } \\
\text { Kelas Kontrol }\end{array}$ \\
\hline Eksperimen & 75,27 & 14,77 \\
\hline Kontrol & 42,05 & 18,73 \\
\hline ES & \multicolumn{3}{c}{$\mathbf{1 , 7 7}$} \\
\hline Kriteria & Tinggi
\end{tabular}

Dari Tabel 4 dapat dilihat bahwa hasil perhitungan Effect Size $=1,77$ dengan kriteria tinggi karena 1,77 berada pada $E S \geq 0,8$. Ini berarti model pembelajaran $S F E$ memberikan pengaruh terhadap kemampuan berpikir kritis matematis siswa yaitu sebesar 1,77 yang masuk pada kriteria tinggi. Hal ini sejalan dengan penelitian yang dilakukan oleh Muslim (2014) yang menyimpulkan bahwa model pembelajaran SFE lebih baik daripada siswa yang mengikuti pembelajaran langsung. Hal ini terlihat dari skor rata-rata kemampuan berpikir kritis matematis siswa di kedua kelas tersebut. Dengan demikian hal ini menunjukkan bahwa model pembelajaran SFE berpengaruh terhadap kemampuan berpikir kritis siswa.

Pengaruh model pembelajaran $S F E$ yang tinggi terhadap kemampuan berpikir kritis matematis siswa dikarenakan model pembelajaan $S F E$ tersebut dirancang untuk mengoptimalkan pembentukan pengetahuan siswa dalam menyerap materi pembelajaran yang disampaikan. Sedangkan pada kelas kontrol, kegiatan pembelajaran yang dilakukan cendrung monoton meskipun guru lebih mudah dalam melakukan pengelolaan kelas. Pembelajaran yang membosankan akan membuat siswa kurang tertarik 
untuk pembelajaran yang berikutnya sehingga hasil belajar yang dicapai belum optimal. Salah satu kelebihan model pembelajaran $S F E$ yang diungkapkan oleh Istarani (2015:159) adalah menumbuhkan kemampuan siswa dalam menyampaikan pengetahuan yang dimiliki kepada siswa lainnya. Hal ini sesuai dengan kemampuan berpikir kritis dimana siswa dalam menyampaikan ide atau gagasan matematika yang dipelajari harus terampil menerapkan pengetahuan yang dimiliki secara sistematis, terorganisasi dalam mengevaluasi bukti, asumsi, logika, dan bahasa yang mendasari pernyataan orang lain untuk akhir mencapai tujuan pemahaman yang lebih mendalam dari suatu masalah yang dihadapi.

\section{Aktivitas Belajar Siswa}

Lembar observasi digunakan untuk mengetahui aktivitas siswa selama mengikuti pembelajaran dengan menggunakan model pembelajaran SFE. Pengamatan yang dilakukan selama dua kali pertemuan yang dilakukan oleh 3 orang pengamat, secara ringkas dinyatakan dalam Tabel 5 sebagai berikut.

Tabel 5. Hasil Aktivitas Siswa

\begin{tabular}{ccccc}
\hline \multirow{2}{*}{ No } & Kategori Pengamatan & \multicolumn{2}{c}{ Persentase Aktivitas (\%) } & $\begin{array}{c}\text { Rata-rata } \\
\text { Keseluruhan } \\
\text { Persentase }\end{array}$ \\
\hline 1 & Pertemuan 1 & Pertemuan 2 & & 84,85 \\
\hline 2 & Visual activities & 86,87 & 82,83 & 72,48 \\
\hline 3 & Oral activities & 69,70 & 75,25 & 82,58 \\
\hline 4 & $\begin{array}{c}\text { Listening } \\
\text { activities }\end{array}$ & 81,82 & 83,33 & 87,88 \\
\hline 5 & Writing activities & 90,15 & 85,61 & 74,62 \\
\hline
\end{tabular}

Dari Tabel 5 dapat dilihat rata-rata persentase aktivitas siswa dari dua kali pertemuan dan tiga orang pengamat. Berdasarkan analisis data hasil pengamatan aktivitas siswa diperoleh bahwa aktivitas siswa setiap indikator dalam kategori aktif dan sangat aktif. Hal ini disebabkan model pembelajaran $S F E$ yang mampu merangsang siswa dalam mengemukakan ide-ide yang mereka miliki. Dalam model pembelajaran SFE siswa yang bertindak sebagai guru bagi siswa lainnya. Hal ini akan mendorong siswa untuk menguasai beberapa keterampilan diantaranya berbicara dan menyimak. Selain itu siswa akan merasa lebih percaya diri, tidak segan untuk bertanya dan menyampaikan pendapat karena rekan sendiri yang menjelaskan. Sejalan dengan pernyataan tersebut, Istarani (2015:159) mengungkapkan salah satu keunggulan model pembelajaran SFE adalah dapat menumbuhkan aktivitas belajar secara mandiri dan berdikari sehingga siswa lebih aktif dalam kegiatan pembelajaran tanpa merasa ragu memaparkan jawaban mereka di depan kelas.

Hal ini juga didukung dengan apa yang dinyatakan oleh Sardiman (2014:97) bahwa dalam kegiatan belajar siswa harus aktif berbuat. Dalam belajar sangat diperlukan aktivitas proses belajar. Belajar aktif merupakan perkembangan teori learning by doing (Siregar dan Nara, 2011:108). Belajar aktif memperkenalkan pendekatan yang lain daripada gambaran rutin pembelajaran yang sekarang ini banyak terjadi. Belajar aktif menuntut keaktifan guru dan juga siswa, oleh karena itu guru perlu mengembangkan berbagai kegiatan belajar yang melibatkan siswa secara aktif dalam kegiatan yang menantang kreativitas siswa.

\section{Motivasi Belajar Siswa}

Angket motivasi belajar siswa dalam penelitian ini merupakan angket yang hanya diberikan kepada siswa kelas eksperimen untuk mengetahui seberapa besar motivasi siswa dengan diterapkan model pembelajaran $S F E$. Angket motivasi yang digunakan berupa pernyataan positif dan pernyataan negatif yang berjumlah 20 pernyataan dan terdiri dari 5 indikator motivasi belajar. Siswa hanya memilih satu jawaban dari 5 pilihan yang diberikan (sangat setuju, setuju, ragu-ragu, tidak setuju dan sangat tidak setuju) yang telah disediakan. Hasil perhitungan rata-rata angket motivasi belajar siswa pada pernyataan positif pada kelas eksperimen dapat dilihat pada Tabel 6 sebagai berikut. 
Tabel 6. Rekapitulasi Perhitungan Rata-rata Hasil Angket Motivasi Belajar Siswa pada Pernyataan Positif untuk Setiap Indikator

\begin{tabular}{|c|c|c|c|c|c|c|c|}
\hline \multirow{2}{*}{ Indikator } & \multicolumn{5}{|c|}{ Jumlah Tanggapan } & \multirow{2}{*}{$\begin{array}{l}\text { Rata-rata } \\
\text { tiap } \\
\text { Indikator }\end{array}$} & \multirow{2}{*}{ Kriteria } \\
\hline & SS & $S$ & $\mathrm{RR}$ & $\mathrm{TS}$ & STS & & \\
\hline $\begin{array}{l}\text { Adanya dorongan dan kebutuhan } \\
\text { dalam belajar }\end{array}$ & 110 & 84 & 3 & 0 & 0 & 4,48 & $\begin{array}{l}\text { Sangat } \\
\text { Tinggi }\end{array}$ \\
\hline $\begin{array}{c}\text { Menunjukan perhatian dan minat } \\
\text { terhadap tugas-tugas yang } \\
\text { diberikan }\end{array}$ & 135 & 148 & 6 & 0 & 0 & 4,38 & $\begin{array}{l}\text { Sangat } \\
\text { Tinggi }\end{array}$ \\
\hline Tekun menghadapi tugas & 90 & 88 & 12 & 0 & 0 & 4,32 & $\begin{array}{l}\text { Sangat } \\
\text { Tinggi }\end{array}$ \\
\hline Ulet menghadapi kesulitan & 90 & 96 & 6 & 0 & 0 & 4,36 & $\begin{array}{l}\text { Sangat } \\
\text { Tinggi }\end{array}$ \\
\hline $\begin{array}{c}\text { Adanya hasrat dan keinginan } \\
\text { berhasil }\end{array}$ & 150 & 128 & 9 & 2 & 0 & 4,38 & $\begin{array}{l}\text { Sangat } \\
\text { Tinggi }\end{array}$ \\
\hline \multicolumn{6}{|c|}{ Rata-Rata Keseluruhan } & 4,38 & $\begin{array}{l}\text { Sangat } \\
\text { Tinggi }\end{array}$ \\
\hline
\end{tabular}

Dari Tabel 6 dapat dilihat bahwa rata-rata motivasi belajar siswa untuk pernyataan positif dari kelima indikator tersebut secara keseluruhan memiliki kriteria sangat tinggi dengan nilai rata-rata keseluruhan 4,38. Selanjutnya untuk hasil perhitungan rata-rata angket motivasi belajar siswa pernyataan negatif pada kelas eksperimen dapat dilihat pada Tabel 7 berikut.

Tabel 7. Rekapitulasi Perhitungan Rata-rata Hasil Angket Motivasi Belajar Siswa pada Pernyataan Negatif untuk Setiap Indikator

\begin{tabular}{|c|c|c|c|c|c|c|c|}
\hline \multirow{2}{*}{ Indikator } & \multicolumn{5}{|c|}{ Jumlah Tanggapan } & \multirow{2}{*}{$\begin{array}{l}\text { Rata-rata } \\
\text { tiap } \\
\text { Indikator }\end{array}$} & \multirow{2}{*}{ Kriteria } \\
\hline & SS & S & $\mathrm{RR}$ & $\mathrm{TS}$ & STS & & \\
\hline $\begin{array}{l}\text { Adanya dorongan dan kebutuhan dalam } \\
\text { belajar }\end{array}$ & 1 & 2 & 6 & 64 & 120 & 4,39 & $\begin{array}{l}\text { Sangat } \\
\text { Tinggi }\end{array}$ \\
\hline $\begin{array}{l}\text { Menunjukan perhatian dan minat } \\
\text { terhadap tugas-tugas yang diberikan }\end{array}$ & 1 & 2 & 12 & 84 & 85 & 4,18 & Tinggi \\
\hline Tekun menghadapi tugas & 2 & 4 & 6 & 36 & 30 & 3,55 & Tinggi \\
\hline Ulet menghadapi kesulitan & 0 & 12 & 30 & 104 & 10 & 3,55 & Tinggi \\
\hline Adanya hasrat dan keinginan berhasil & 1 & 4 & 3 & 40 & 35 & 3,77 & Tinggi \\
\hline \multicolumn{6}{|c|}{ Rata-Rata Keseluruhan } & 3,89 & Tinggi \\
\hline
\end{tabular}

Dari Tabel 7 dapat dilihat bahwa rata-rata motivasi belajar siswa untuk pernyataan negatif dari kelima indikator tersebut secara keseluruhan memiliki kriteria tinggi dengan nilai rata-rata keseluruhan 3,89. Secara keseluruhan rata-rata motivasi belajar siswa baik dari pernyataan positif dan pernyataan negatif dapat dilihat pada Tabel 8 berikut ini.

Tabel 8. Rekapitulasi Perhitungan Rata-rata Hasil Angket Motivasi Belajar Siswa untuk Seluruh Indikator

\begin{tabular}{|c|c|c|c|c|c|c|c|}
\hline \multirow{2}{*}{ Motivasi } & \multicolumn{5}{|c|}{ Jumlah Tanggapan } & \multirow{2}{*}{ Rata-rata } & \multirow[t]{2}{*}{ Kriteria } \\
\hline & SS & $S$ & $\mathrm{RR}$ & $\mathrm{TS}$ & STS & & \\
\hline Positif & 575 & 544 & 36 & 2 & 0 & 4,38 & Sangat Tinggi \\
\hline Negatif & 5 & 24 & 57 & 328 & 280 & 3,89 & Tinggi \\
\hline \multicolumn{6}{|c|}{ Rata-Rata Keseluruhan } & 4,14 & Tinggi \\
\hline
\end{tabular}


Dari Tabel 8 dapat dilihat bahwa rata-rata motivasi belajar siswa untuk pernyataan positif dan negatif pada semua indikator berada pada kriteria tinggi dengan jumlah 22 siswa menghasilkan rata-rata keseluruhan siswa adalah 4,14 dengan kriteria tinggi karena berada pada kisaran $3,4<\bar{X} \leq 4,2$.

Motivasi diperlukan untuk mengarahkan seseorang agar melakukan suatu tindakan. Tingginya motivasi belajar siswa kelas eksperimen pada penelitian ini dikarenakan pada model pembelajaran SFE, siswa tidak langsung diberikan hasil akhir dari penyelesaian, melainkan siswa dilatih untuk belajar menyelesaikan masalah dengan cara mereka sendiri melalui diskusi bersama teman sekelompoknya dengan bantuan guru kemudian menyampaikan kembali kepada siswa lainnya di depan kelas sehingga menimbulkan keingintahuan mereka untuk bisa menyelesaikan masalah yang secara tidak langsung memotivasi keinginan siswa untuk belajar. Hal ini sejalan dengan penelitian yang dilakukan oleh Nurhayati (2016) yang menyatakan bahwa terdapat perbedaan motivasi yang signifikan antara kelas yang mendapat model pembelajaran $S F E$ dengan kelas yang mendapat model pembelajaran langsung. Ini berarti model pembelajaran $S F E$ berpengaruh besar terhadap motivasi belajar siswa.

\section{KESIMPULAN DAN SARAN}

Berdasarkan hasil pengelolaan data hasil penelitian dan pembahasan secara umum dapat disimpulkan bahwa model pembelajaran Student Facilitator and Explaining (SFE) dapat memberikan pengaruh yang tinggi terhadap kemampuan berpikir kritis siswa pada materi aljabar kelas VIII SMP Negeri 13 Singkawang. Sesuai dengan sub-sub rumusan masalah penelitian, secara khusus dapat disimpulkan hal-hal sebagai berikut.

1. Terdapat perbedaan kemampuan berpikir kritis antara siswa yang mendapatkan model pembelajaran Student Facilitator and Explaining (SFE) dengan siswa yang mendapatkan model pembelajaran langsung pada materi aljabar kelas VIII SMP Negeri 13 Singkawang.

2. Model pembelajaran Student Facilitator and Explaining (SFE) memberikan pengaruh yang tergolong tinggi terhadap kemampuan berpikir kritis siswa pada materi aljabar kelas VIII SMP Negeri 13 Singkawang.

3. Aktivitas belajar siswa selama pembelajaran dengan menggunakan model Student Facilitator and Explaining (SFE) sangat aktif.

4. Motivasi belajar siswa tergolong tinggi terhadap model pembelajaran Student Facilitator and Explaining (SFE).

Penelitian ini masih memiliki banyak kekurangan, maka dari itu penulis mengharapkan masukan dan saran yang membangun dari pembaca untuk hasil yang lebih baik. Semoga artikel ini dapat bermanfaat bagi pembaca, terutama bagi saya calon pendidik yang akan menjalankan profesi sebagai pendidik dalam rangka meningkatkan mutu pendidikan.

\section{DAFTAR PUSTAKA}

Buyung, B., Sumarli, S., \& Rosmaiyadi, R. (2020). Development of problem based learning based on ethnomatematics to support students' mathematics literacy ability and selfconfidence. In AIP Conference Proceedings (Vol. 2268, No. 1, p. 030002). AIP Publishing LLC.

Fisher, Alec. (2009). Berpikir Kritis Sebuah Pengantar. Jakarta: Erlangga

Haryani, Desti. (2012). Membentuk Siswa Berpikir Kritis Melalui Pembelajaran Matematika. Jurnal Universitas Palangkaraya

Huda, Miftahul. (2014). Model-Model Pengajaran dan Pembelajaran. Yogyakarta: Pustaka Pelajar.

Istarani. (2015). 50 Tipe, Strategi dan Teknik Pembelajaran Kooperatif. Medan: Media Persada

Johnson, Elaine. (2011). Contextual Teaching and Learning. Bandung: Kaifa. 
Kusumaningrum, Anggita Dwijayanti. (2013). Peningkatan Aktivitas dan Hasil Belajar Siswa Kelas IV pada Materi Koperasi melalui Model Pembelajaran Kooperatif Tipe Student Teams Achievement Devision di SD Negeri Tegal Sari 8 Kota Tegal. Skripsi Universitas Negeri semarang.

Langgeng, Abraham Rinekso. (2012). Pengaruh Penerapan Metode Pembelajaran Student Facilitator and Explaining Terhadap Minat Belajar Siswa pada Mata Pelajaran TIK di SMAN 1 Mertoyudan. Skripsi Universitas Negeri Yogyakarta.

Lestari, K.E., dan Yudhanegara, M.R. (2015). Penelitian Pendidikan Matematika: Panduan Praktis Menyusun Skripsi, Tesis, dan Karya Ilmiah dengan Pendekatan Kuantitatif, Kualitatif, dan Kombinasi disertai dengan Model dan Kemampuan Matematis. Bandung: PT Refika Aditama

Munafiah, Siti. (2015). Efektivitas Penggunaan Model Pembelajaran Missouri Mathematics Project untuk Meningkatkan Kemampuan Berpikir Kritis Peserta Didik Kelas VIII Semester Gasal pada Materi Fungsi di SMPN 3 Pabelan. Skripsi Universitas Islam Negeri Walisongo Semarang.

Muslim, Siska Ryane. (2014). Pengaruh Penggunaan Metode Student Facilitator and Explaining Dalam Pembelajaran Kooperatif Terhadap Kemampuan Pemecahan Masalah Matematik dan Kemampuan Berpikir Kritis Matematik Siswa SMK di Kota Tasikmalaya. Jurnal Universitas Terbuka Tasikmalaya.

Nur'aini, Dewi. (2016). Analisis Kemampuan Berpikir Kritis Matemtais Siswa Kelas VII Materi Segiempat SMP Negeri 7 Singakawang. Skripsi Pendidikan Matematika STKIP Singkawang.

Nurhayati, Siti. (2016). Pengaruh Model Pembelajaran Student Facilitator and Explaining Terhadap Motivasi Belajar siswa di Sekolah Menengah Kejuruan Taruna Satria Pekanbaru. Skripsi Universitas Islam Negeri Sultan Syarif Kasim Riau.

Permendiknas. (2006). Peraturan Menteri Pendidikan Nasional Republik Indonesia Nomor 23 Tahun 2006 Tentang Standar Isi Sekolah Menengah Pertama. Jakarta: BSNP

Prihatiningtyas, N.C., dan Nurhayati. (2017). Penerapan Model Pembelajaran Means-Ends Analysis Untuk Meningkatkan Kemampuan Pemecahan Masalah Matematis Siswa. JPMI (Jurnal Pendidikan Matematika Indonesia), 2(1), 13-18.

Rolia, R., Rosmaiyadi, \& Husna, N. (2017). Pengaruh Model Pembelajaran Creative Problem Solving Terhadap Kemampuan Berpikir Kreatif Siswa pada Materi Program Linier Kelas XI SMK. VOX EDUKASI, 8(2), 72-82.

Rosmaiyadi. (2017). Analisis Kemampuan Berpikir Kritis Matematis Siswa dalam Learning Cycle $7 E$ Berdasarkan Gaya Belajar. JPMII 2(1). 12-19.

Santoso, Hadi. (2009). Pengaruh Penggunaan Laboratorium Riil Dan Laboratorium Virtuil pada Pembelajaran Fisika Ditinjau dari Kemampuan Berpikir Kritis Siswa. Tesis Universitas Sebelas Maret Surakarta.

Sardiman. (2014). Interaksi Motivasi Belajar Mengajar. Jakarta: PT. Raja Grafindo Persada.

Shoimin, Aris. (2014). 68 Model Pembelajaran Inovatif dalam Kurikulum 2013. Yogyakarta: Arruzz Media.

Siregar, E., dan Nara, H. (2011). Teori Belajar dan Pembelajaran. Jakarta: GI

Sumarna. (2013). Pembelajaran Quantum dan Optimalisasi Kecerdasan. Bandung: ALFABETA 